$\overline{\overline{\text { BRUSSELS }}} \overline{\overline{\text { STUDIES }}}$

\section{Brussels Studies}

La revue scientifique électronique pour les recherches sur Bruxelles / Het elektronisch wetenschappelijk tijdschrift voor onderzoek over Brussel / The e-journal for academic research on Brussels

Collection générale | 2010

\title{
Kuregem: van afbraak naar herwaardering
}

Cureghem: de la démolition à la revitalisation

Cureghem: from demolition to revitalisation

\section{Muriel Sacco}

Traducteur : Ben Winant

\section{CpenEdition}

Journals

Édition électronique

URL : http://journals.openedition.org/brussels/812

DOI : $10.4000 /$ brussels.812

ISSN : 2031-0293

Éditeur

Université Saint-Louis Bruxelles

Référence électronique

Muriel Sacco, « Kuregem: van afbraak naar herwaardering », Brussels Studies [Online], Algemene collectie, nr 43, Online op 25 octobre 2010, geraadpleegd op 20 avril 2019. URL : http://

journals.openedition.org/brussels/812 ; DOI : 10.4000/brussels.812 
www.brusselsstudies.be Nummer 43, 4 oktober 2010. ISSN 2031-0293

Muriel Sacco

\section{Kuregem: van afbraak naar herwaardering}

Vertaling : Benny Winant

Dit artikel handelt over de veranderingen waartoe het nieuwe overheidsbeleid voor de herwaardering van de " achtergestelde " wijken de aanzet heeft gegeven. De analyse van de wijkcontracten voor Kuregem verschaft meer inzicht in de manier waarop de bestaande context zijn stempel op de institutionele vernieuwing drukt en in de wijze waarop een nieuw overheidsbeleid het politieke handelen stuurt. Met de invoering van de wijkcontracten zijn de gemeentelijke overheden van Anderlecht overgegaan van een afbraakproject naar een herwaarderingsproject voor Kuregem. Die overgang verliep evenwel geleidelijk. Bij het begin van de uitvoering van de wijkcontracten voor Kuregem was de gemeente passief en onverschillig ten gevolge van haar politieke en administratieve cultuur en haar gebrek aan betrokkenheid bij het nieuwe project. Dankzij een gedeeltelijke wijziging van het lokale politieke landschap en de leerprocessen in het kader van de wijkcontracten werden de doelstellingen van het gewestelijk beleid gerealiseerd. Het geval Kuregem toont aldus aan dat lokale actoren een cruciale rol spelen bij het uitvoeren van het overheidsbeleid.

Muriel Sacco is onderzoekster politieke wetenschappen, lid van METICES en van CENA van de Université Libre de Bruxelles (ULB). In het kader van het programma "Prospective Research for Brussels » van het IWOIB werkt ze aan een doctoraatsthesis "L'impact des politiques publiques et de la mobilisation des acteurs privés dans les projets de développement urbain. Etude comparée Bruxelles-Montréal ». Samen met Gaël Comhaire heeft ze "Le tournant socio-économique des Contrats de quartier », Année Sociale, 2007 geschreven.

Contact gegevens : 


\section{Inleiding 1}

Kuregem staat regelmatig in de belangstelling: onveiligheidsgevoelens, sociale ontreddering van de inwoners, allerhande criminele feiten, politiecontroles enz. Zoals in andere centrumwijken van Brussel resulteerde de langdurige desinteresse van de gemeente in de fysieke verloedering van de wijk en in de toename van de sociale problemen. Vanaf de jaren 1990 hebben het gewestelijke, het federale en het Europese niveau die problemen naar zich toe getrokken en opnieuw belangstelling voor de " gevoelige wijken " getoond in de vorm van nieuwe beleidsmaatregelen: het $\mathrm{FIM}^{2}$, de veiligheids- en preventiecontracten of nog het federaal grootstedenbeleid (FGSB). Die « op de gemeenten gerichte beleidsmaatregelen » (Nagels en Rea, 2007) verlenen de gemeenten een belangrijke rol en zorgen voor de financiering van acties in de meest achtergestelde wijken acties die gevoerd worden door gemeenten die kampen met financiële problemen ten gevolge van hun financieringswijze, de desindustrialisatie, de stadsverloedering, de grote concentratie van achtergestelde bevolkingsgroepen en de exodus van de middenklasse naar de rand. Paradoxaal genoeg stoot de uitvoering van die acties in bepaalde gemeenten op weerstand.

Dat fenomeen wordt verduidelijkt door de wijze waarop de gemeente Anderlecht de wijkcontracten voor Kuregem beheerde ${ }^{3}$. Deze casestudy vestigt de aandacht op de problemen om het overheidsoptreden in de Brusselse centrum- en migrantenwijken als nieuwe beleidsprioriteit te legitimeren en om nieuwe lokale beheerspraktijken toe te passen. In een neo-institutionalistisch perspectief verklaart de casestudy tegelijk hoe de reeds bestaande context de institutionele vernieuwing beïnvloedt en hoe een nieuw overheidsbeleid zijn stempel op het politieke handelen drukt. Bovendien benadrukt onze analyse dat de politieke gevoeligheden van de lokale personeelsleden die het overheidsbeleid moeten uitvoeren, een cruciale rol spelen. Daartoe baseren we ons op een kwalitatief onderzoek dat bestaat uit semi-geleide ge-

\footnotetext{
${ }^{1}$ Dit artikel is gebaseerd op een lopend doctoraatsonderzoek over de vergelijking van het nieuwe overheidsbeleid dat in Brussel en Montréal wordt gevoerd tegen sociaalruimtelijke segregatie, onder leiding van Andrea Rea (hoogleraar sociologie aan de ULB, Métices) en Serge Jaumain (hoogleraar geschiedenis aan de ULB, CENA) en gefinancierd in het kader van het programma "Prospective research for Brussels " van het IWOIB. Het doctoraatsonderzoek strekt ertoe de graad van convergentie en homogenisering van het overheidsoptreden die gepaard gaat met de uitvoering van dat type overheidsbeleid te bepalen. Wegens de specifieke kenmerken van dat beleidstype is de demonstratie gebaseerd op verschillende casestudy's in de twee steden die toegespitst zijn op de wijken waarvoor dat beleid bestemd is, teneinde de totstandkomingsprocessen in kaart te brengen.

2 Het Impulsfonds voor het Migrantenbeleid

${ }^{3}$ Voor een overzicht van de uitvoering van het nieuwe stadsbeleid in Kuregem, verwijzen we naar het eindwerk van Laurent Picard van 2007 voor het behalen van de graad stedenbouwkundige aan het Institut Supérieur d'Urbanisme et de Rénovation Urbaine van Brussel met als titel Outils, acteurs et projet de revitalisation urbaine : l'exemple de Cureghem en Région de Bruxelles-Capitale.
} 
sprekken met actoren die het overheidsbeleid mee uitstippelen, documentenonderzoek en een persoverzicht.

We beginnen met een beknopte beschrijving van de hoofdkenmerken van de wijkcontracten. Daarna behandelen we de knelpunten bij de nieuwe aanpak van het overheidsoptreden in Kuregem. Ten slotte buigen we ons over de factoren die de gedeeltelijke en geleidelijke wegwerking van de knelpunten verklaren.

\section{Kenmerken van de wijkcontracten}

De wijkcontracten zijn in de plaats gekomen van de renovatieprojecten voor huizenblokken (1977), die het vooropgezette aantal woningen niet hebben geproduceerd wegens een gebrek aan belangstelling vanwege de gemeenten en wegens de logge administratieve procedures die gepaard gingen met de uitvoering (Noël, 1998). De ordonnantie van 7 oktober 1993 houdende herwaardering van de wijken voert een nieuw instrument voor het overheidsbeleid in om de efficiëntie van het overheidsoptreden te verhogen. De wijkcontracten verschillen op verschillende vlakken van het traditionele welzijns- en huisvestingsbeleid. Ten eerste zijn ze gebaseerd op een territoriale benadering. Er worden prioritaire gebieden afgebakend om de middelen te concentreren op de meest achtergestelde zones. Dat is een breuk met het principe van de algemene herverdeling van de overheidsmiddelen, dat kenmerkend is voor de voorzorgstaat. In het algemeen selecteert de gewestregering elkaar jaar drie of vier wijken binnen de Ruimte voor Versterkte Ontwikkeling van de Huisvesting en de Stadsvernieuwing (RVOHS), die grotendeels de centrumwijken van de eerste Brusselse kroon bestrijkt. Die ruimte werd afgebakend aan de hand van zowel ecologische als sociale indicatoren: de hoge concentratie van verloederde of leegstaande gebouwen, het gebrek aan comfort in de woningen, de verloedering van de openbare ruimten, de hoge bevolkingsdichtheid, het werkloosheidscijfer en het aantal leerlingen die afhaken op school ${ }^{4}$.

Ten tweede houdt de geïntegreerde of allesomvattende benadering van de wijkcontracten rekening met zowel de stedelijke als sociale vraagstukken. Dat vormt de aanzet tot de overschakeling van de renovatie van gebouwen naar herwaardering van de wijken met aandacht voor de verschillende oorzaken van het verval (Thibault, 2001). In concreto hebben de wijkcontracten betrekking op geconventioneerde sociale en middelgrote woningen die door de overheid of in partnerschap met privéontwikkelaars worden gebouwd (delen 1 tot 3), op de renovatie van openbare ruimten (deel 4), op de aanleg van collectieve voorzieningen zoals sportzalen, wijkhuizen of nog crèches en op de financiering van projecten voor sociale en economische herwaardering van de wijken zoals socioprofessionele herinschakeling of steun bij lichte woningrenovatie (deel 5).

De wijkcontracten staan voor een projectmatige aanpak. Ze doen een beroep op de actoren - zowel actoren uit de overheidssector, de privésector en de verenigingen als de bewoners - van het gebied in kwestie om na te denken over de toekomst op basis van de bestaande situatie, de beschikbare middelen en de doelstellingen van het overheidsbeleid (Pinson, 2004). Het is de bedoeling om een netwerk

4 Deloitte \& Touche, Ariès en Moritz, Benoît, 2001, Bilan des Contrats de quartier 19941998 en Région bruxelioise. Phase B. Mise en cuvre des programmes, Brussel, p. 3. 
met de verschillende actoren te creëren en samenwerking met de overheid tot stand te brengen op een manier die afwijkt van de klassieke top-down en hiërarchische benadering van lokale projecten en die meer rekening houdt met de lokale specifieke kenmerken. Het voorgestelde partnerschap gaat verder dan de publiek-private samenwerking (PPS). Deze nieuwe manieren om het overheidsoptreden uit te stippelen leiden tot een diversificatie van de knowhow en van de aangewende middelen, in zoverre de wijze en procedures van uitwerking even belangrijk blijken te zijn als de inhoud van het project zelf. De wijkcontracten bevatten verschillende instrumenten om een beroep te doen op de lokale actoren: voor de privéactoren, de gezamenlijke productie van woningen in deel 3 en de verwachte aanstekelijkheidseffecten; voor de bewoners en de verenigingen van de wijk, mogelijkheid van inspraak en overleg (plaatselijke commissie voor geïntegreerde ontwikkeling en algemene vergadering van de bewoners). Ondanks het grote aantal actoren die betrokken worden bij de uitvoering van het project, behoudt de politieke actor evenwel een centrale plaats, aangezien hij onder meer de actoren moet sturen en de prioriteiten moet vaststellen.

Ten vierde, zoals uit de benaming blijkt, zijn de wijkcontracten gebaseerd op een contractualisering van het overheidsbeleid. In het contract tussen het gewestelijk niveau en de gemeente worden aldus een 4jarig lokaal actieprogramma en de uitvoeringswijze vastgelegd. Daarbij komen nog 2 jaar voor het uitvoeren van de vastgoedprojecten. Het contract stelt het bedrag van de gewestelijke tegemoetkoming vast. Het contract dient aldus om het rendement van het overheidsoptreden te verhogen door de termijnen voor de uitvoering van de overheidsprojecten in te korten, de beschikbare financiële middelen te beperken en de gemeenten te responsabiliseren via verplichte cofinanciering.

Ten slotte impliceren de contractualisering en de projectmatige aanpak een decentralisatie waarbij het lokale niveau als het geschikste niveau wordt beschouwd om oplossingen te vinden voor de crisis waarin de wijken verkeren (Rea, 1999; Schaut, 2007). De herwaardering van het lokale niveau gaat gepaard met de invoering van een specifieke politieke en administratieve cultuur, waar de traditionele overheidsactoren een stap opzij zetten om het uitwerkingsproces open te stellen voor de betrokken doelgroepen en actoren. 


\title{
2. Een moeilijk begin
}

\subsection{Omstreden resultaten}

Sinds 1997 zijn er 6 wijkcontracten gesloten voor Kuregem ${ }^{5}$. Ze hebben het imago en de fysieke omgeving van de wijk gewijzigd door onder meer bouwvallen te verwijderen, openbare ruimten in te richten en tegemoet te komen aan bepaalde behoeften van de bewoners op het vlak van huisvesting of uitrusting. Ze hadden echter ook hun disfuncties. Hoewel de wijkcontracten niet dienen om alle problemen in een wijk op te lossen en de doelstellingen niet altijd duidelijk ${ }^{6}$ zijn, had de herwaardering van de wijk ingrijpender kunnen zijn. Verschillende projecten zijn immers mislukt, hebben jaren aangesleept (sporthal aan de Scheikundigestraat, crèche aan het Lemmensplein) of hebben veel meer geld gekost dan oorspronkelijk was geraamd. De infrastructuren worden onvoldoende benut of de afwerking van de nieuwe woningen laat te wensen over. Een deel van die mislukkingen kan weliswaar worden toegeschreven aan de gebrekkige kennis van het gemeentebestuur van de regels van de wijkcontracten of aan vandalisme, maar ook aan het (wan)beheer en (het gebrek aan) de politieke wil van de lokale bestuurders, het ontbreken van een langetermijnvisie over het gebruik van de nieuwe collectieve voorzieningen of de moeizame participatie van de bewoners. De kritiek komt niet alleen van buitenaf, van de bewoners of de verenigingen. Een lid van de lokale PS-afdeling stelt vast:

\begin{abstract}
Volgens mij was er in Anderlecht zeer duidelijk wanbeheer. Ik kan dat zeker weten, omdat we in 1997 zelf aan de macht waren. Het wanbeheer was dus niet enkel te wijten aan de politieke meerderheid. [...] Ik vind dat de zaken na vier wijkcontracten niet genoeg geëvolueerd zijn. Ik vind dat een vrij uitzonderlijke situatie in Brussel, waar men hetzelfde gebied voor de derde keer gaat herwaarderen. [...] Het is dan ook duidelijk dat de behoeften in de centrumwijken van Brussel zo groot zijn dat er meer dan een wijkcontract nodig is. Ik vind het ongelooflijk dat men zich na drie wijkcontracten nog altijd in een situatie bevindt die toch niet ideaal is.
\end{abstract}

Op de volgende pagina's zullen we aantonen in hoeverre de verschillende gemeentelijke meerderheden verantwoordelijk gesteld kunnen worden voor die omstreden resultaten. We zullen de nadruk op twee elementen leggen: het gebrek aan legitimiteit van de ingrepen in de Kuregemwijk en de kloof met de nieuwe administratieve en politieke cultuur die via de wijkcontracten wordt beoogd.

\subsection{Kuregem op de politieke agenda}

In een context van intense politisering van de integratie van buitenlanders die zich met de naoorlogse migratiegolven in ons land hebben gevestigd, hebben de wijkcontracten op hun manier overheidsingrepen in de achtergestelde en migrantenwijken opgelegd en er een beleidsprioriteit voor de gemeenten van gemaakt. Wegens

\footnotetext{
${ }^{5}$ De zes wijkcontracten voor Kuregem: Dauwwijk (1997-2001), Grondels-Herziening (19992003), Péqueur-Luchtvaart (2000-2004), Scheikundige (2001-2005), Raad (2004-2008) en Lemmens (2007-2011). Een zevende wijkcontract, Kanaal-Zuid, wordt sinds 2009 bestudeerd.

${ }^{6}$ We verwijzen naar de impliciete doelstellingen om de gevestigde bevolking te vervangen en gentrificatie te bevorderen onder het mom van een beleid tegen sociale uitsluiting. Cf. het rapport van het Rekenhof aan de Kamer van Volksvertegenwoordigers Het federale grootstedenbeleid: onderzoek van de stads- en huisvestingscontracten 2005-2007 van december 2007, pp. 47-48. Er zij eveneens verwezen naar het artikel van Mathieu Van Criekingen en Julie Charles (2007) en naar het werk van Abdelfattah Touzri (2007).
} 
de concentratie van personen van vreemde origine in de RVOHS worden de wijkcontracten ingedeeld bij de categorie van het overheidsbeleid inzake integratie en sociale compensatie, in zoverre dat beleid bevolkingsgroepen die daartoe de middelen niet hadden, toegang bood tot socioculturele en sociosportieve evenementen (Rea, 2006). In het Brussels Gewest waren sommige van die wijken verwaarloosd door de politici. Dat werkte vastgoedspeculatie, achteruitgang van de residentiële functie van de stad en fysieke verloedering (Schoonbrodt, 2007) in de hand.

In het zuidwesten van de Vijfhoek ligt Kuregem ingeklemd tussen het Zuidstation, de spoorlijn, het Kanaal Brussel-Charleroi en de lanen van de Kleine Ring. De wijk is door het kanaal afgesneden van de andere wijken van Anderlecht. Kuregem is al verschillende decennia een transitwijk, een toegangspoort tot de stad voor nieuwe migranten die er zich vestigen in afwachting van een verbetering van hun sociaaleconomische situatie. De wijk heeft een grote arbeiders- en migrantenbevolking ${ }^{7}$ en heeft zwaar te lijden gehad onder de gevolgen van de desindustrialisatie: stijging van de werkloosheid, toename van het aantal bouwvallen, verloedering van de stad, samenlevingsproblemen, onveiligheidsgevoelens of nog toename van het aantal jongeren die afhaken op school.

Kuregem is niet alleen een geografisch en sociaal geïsoleerde wijk, maar werd ook in de steek gelaten door het gemeentebestuur. Aangezien de bevolking hoofdzakelijk uit migranten bestond, was de wijk van weinig electoraal belang (Meert, Mistiaen en Kesteloot, 1995). De onverschilligheid van de politici kwam niet alleen tot uiting in de aanduiding van de gemeentegrens ${ }^{8}$, maar ook in de inhoud en de uitvoeringswijze van bepaalde projecten die voor de wijk bestemd waren. De gemeente had onder meer gepland een deel van de wijk te slopen om er een weg aan te leggen naar het industriepark (Schoonbrodt, 2007) of om een aantal woon- en kantoortorens te bouwen naar het model van de Noordwijk (Mistiaen, 1994). Die projecten voor de ontwikkeling van de gemeente waren een uiting van het institutionele en politieke racisme van het gemeentebestuur ${ }^{9}$, dat de bevolking van Kuregem als een gevaarlijke en ongewenste bevolkingsgroep beschouwde. Na de rellen van 1991 verklaarde Jacques Simonet, leider van de liberale oppositie, toekomstige schepen en daarna burgemeester van Anderlecht, dat hij gekant was tegen uitbreidingen van het sociale preventiebeleid in dat soort wijken. Er moest een einde worden gemaakt aan de financiering van de integratieprogramma's voor migranten en die financiële middelen moesten naar de politie gaan (Rea, 1999). Met de steun van onder meer de socialistische burgemeester Christian D'Hoogh, die iets later verklaarde: « ca-

\footnotetext{
${ }^{7}$ Arbeiders en migranten kwamen in Kuregem wonen wegens de bescheiden huurprijzen voor de woningen die leeg kwamen te staan na het vertrek van de middenklasse naar de rand (Mistiaen, Meert en Kesteloot, 1995). Die volks- en migrantenwijken zijn blijven bestaan wegens de economische crisis. In Kuregem maken de bewoners met allochtone roots ongeveer twee derde van de bevolking uit (Mistiaen, 1994).

8 Het bord bij het binnenrijden van de gemeente Anderlecht bevond zich juist na het verlaten van Kuregem, bij het begin van de Wayezstraat, met andere woorden, aan de andere kant van het kanaal.

${ }^{9}$ Volgens Andrea Rea (2006) komt het institutionele en politieke racisme tot uiting in de weigering van bepaalde Brusselse gemeenten om buitenlanders in te schrijven, in een openlijk racistisch discours tegenover migranten van alle traditionele partijen en in de weigering om hun stemrecht te verienen.
} 
chez ce Cureghem que je ne saurais voir " $^{10}$, sprak J. Simonet in zijn kritiek op het integratie- en samenlevingsbeleid van P. Reniers ${ }^{11}$ van het terugsturen van illegale migranten naar hun land van herkomst of nog van meer veiligheid en een strengere aanpak van buitenlanders ${ }^{12}$.

Tot in het midden van de jaren 1990 waren de grootste partij in de gemeenteraad, de PS (Parti Socialiste), die de gemeente al verschillende decennia bestuurde, en de PRL (Parti Réformateur Libéral) ${ }^{13}$, de grootste oppositiepartij van de gemeente tot in 1993, het erover eens dat er zo weinig mogelijk moest worden ingegrepen in Kuregem. Daardoor duwden ze de wijk en haar bewoners nog meer in de marginaliteit. Er was al een eerste poging tot overlegd, geïntegreerd en doelgericht ingrijpen in Kuregem ondernomen, maar de politieke en administratieve vijandigheid tegen ingrepen in de wijk heeft die poging afgezwakt. Tussen 1989 en 1994 experimenteerde Pierre Reniers, PSC-schepen voor stedenbouw, stadsvernieuwing en verenigingsleven, met een geïntegreerde benadering van de herwaardering van de wijk ${ }^{14}$. In juni 1989 werd trouwens een Handvest voor Sociale Ontwikkeling goedgekeurd door de gemeenteraad aan de vooravond van het bezoek aan Kuregem door de leden van het Europees netwerk « heropleving van de crisiswijken » (Jacquier, 1991). De Sociale Buurtontwikkeling werd weliswaar officieel erkend, maar het gemeentebestuur bleef passief bij de uitwerking en uitvoering van het actieprogramma, terwijl het nieuwe Zuidstation vastgoedspeculatie in de wijk bevorderde. Bovendien werd P. Reniers uitgemaakt voor « schepen van de bougnouls» door leden van de gemeenteraad en ambtenaren wegens zijn plannen met Kuregem.

In 1997 kende het Brussels Hoofdstedelijk Gewest het eerste wijkcontract toe aan de gemeente Anderlecht voor de Dauwwijk in Kuregem. Dat was onbetwistbaar de overgang van een afbraak- naar een herwaarderingsproject. Dat keerpunt mag evenwel niet overschat worden. Het project dat de gemeente in verschillende wijkcontracten steunde, kwam nog niet overeen met de filosofie van de wijkcontracten inzake herstel van de residentiële functie en renovatie van de openbare ruimten in de achtergestelde wijken noch met de nieuwe praktijken op het vlak van stadsconceptie. Enerzijds zag de gemeentelijke meerderheid de herwaardering van de wijk als de herwaardering van de handel in wagens wegens het potentieel van die sector voor de interne lokale ontwikkeling, de continuitteit van de handelsfunctie en de historische functie van de sector. Die benadering hield geen rekening met de milieuoverlast die veroorzaakt wordt door dat soort activiteiten, met de onverenigbaarheid ervan met de herwaardering van de woonfunctie in de centrumwijken van Brussel

10 Couvreur, Daniel ; VUILle, Nicolas ; HannaERT, Pierre, " Anderlecht connaît déjà son champion », in Le Soir, zaterdag 1 oktober 1994.

11 «Simonet répond à Reniers », in Le Soir, vrijdag 1 juli 1994.

12 VUILLE, Nicolas, "L'immigration, la sécurité et la propreté comme thèmes de campagne, Jacques Simonet déjà en $1^{\text {er }}$ échevin d'Anderlecht ", in Le Soir, dinsdag 3 november 1993.

${ }^{13}$ In mei 2002 hebben de PRL, het Front Démocratique des Francophones (FDF) en de Mouvement des Citoyens Catholiques samen de Mouvement Réformateur opgericht.

14 De Sociale Buurtontwikkeling (SBO) was een programma in het kader van het Europees netwerk voor de heropleving van de crisiswijken, dat in 1989 in Kuregem werd uitgevoerd. De SBO streefde doelstellingen na die vergelijkbaar waren met die van de wijkcontracten op het vlak van lokale economische en sociale ontwikkeling, verbetering van de fysieke leefomgeving en opbouw van de sociale banden, maar met meer bescheiden instrumenten en middelen. De $\mathrm{SBO}$ is trouwens een van de inspiratiebronnen van de wijkkcontracten. 
en evenmin met de conclusies van de SBO, die omkadering en geleidelijke afbouw van die activiteit aanbevalen (Mistiaen, 1994). Anderzijds trof de gemeente niet alle maatregelen waar ze bevoegd was, zoals het onderhoud van de bestaande gemeentelijke voorzieningen of maatregelen om de autodruk in bepaalde straten te verlichten, teneinde de kwaliteit van de openbare ruimten te verbeteren. Vervolgens werden bepaalde inrichtingskeuzen meer ingegeven door een visie op de wijkherwaardering die veiligheid centraal stelde. Dat toont aan dat die keuzen meer ingegeven waren door het wantrouwen jegens de bewoners dan door het streven om hun leefomgeving te verbeteren. Ten slotte werd de in de wijkcontracten voorgestelde samenwerking met de bewoners en de wijkverenigingen bij het vastleggen van het actieprogramma vaak verwaarloosd en zelfs vermeden door de lokale elite.

De desinteresse en het wantrouwen van de gemeentelijke meerderheid (PS-PRLFDF) van Kuregem gingen weliswaar niet langer gepaard met desinvestering van overheidswege in de wijk, maar de reikwijdte van de herwaardering werd daardoor beperkt. In Kuregem was de gemeentelijke actor volgens de uitdrukking van Ellen Immergut (1992) een grote rem op de herwaardering, namelijk een actor die de uitvoering van het nieuwe programma kan vertragen of blokkeren. De vertegenwoordigers van de lokale actoren in de wijk hebben de impact van het programma afgezwakt. Zoals Jacques de Maillard (2002) onderstreept, verdwijnen de denk- en handelwijzen van actoren en de reeds bestaande cognitieve instellingen niet zodra er een nieuw overheidsbeleid wordt ingevoerd.

\subsection{Weerstand tegen de nieuwe vormen van overheidsingrijpen}

De wijkcontracten hebben niet alleen de bebouwde omgeving en de openbare ruimten van de wijken in kwestie gerenoveerd of nieuwe voorzieningen en diensten aangeboden aan de wijkbewoners, maar ook een aanzet gegeven tot een rationalisering van de overheidsingrepen. Sinds de toekenning van het eerste wijkcontract aan de gemeente Anderlecht, werd dat programma beheerd door de Dienst Stadsvernieuwing (DSV). De DSV werd speciaal daarvoor opgericht en toegevoegd aan de bestaande administratieve structuur om ambtenaren die al andere opdrachten hadden, die taak te besparen. Deze a priori rationele keuze heeft echter de uitvoering van bepaalde projecten vertraagd. De strikte scheiding tussen de verschillende diensten van het gemeentebestuur heeft de DSV geïsoleerd, omdat het veel moeilijker is verschillende diensten dan ambtenaren van eenzelfde dienst te doen samenwerken. Die weerstand tegen samenwerking werd trouwens herhaaldelijk vermeld in verband met de aanvragen tot stedenbouwkundige vergunningen en met het ontwerp, het beheer en het onderhoud van nieuwe woningen en voorzieningen. De samenwerking verliep des te moeilijker daar de personeelsleden van de DSV, met uitzondering van het diensthoofd, nieuwkomers in het lokale openbare ambt waren. De DSV heeft dus zeer weinig voordeel gehaald uit de administratieve en praktische knowhow die in het gemeentebestuur voorhanden was.

De werking van de DSV was des te stroever daar de nieuwe ad hoc dienst te weinig personeelsleden telde. In het begin telde de dienst gemiddeld drie of vier medewerkers: het diensthoofd en technici. Met de toekenning van nieuwe wijkcontracten aan de gemeente was de rotatie van de sociale en technische coördinatoren nadelig voor de permanente followup van de contracten, voor het verwerven van kennis van de procedures, de situatie en de behoeften van de wijk. Het personeelsverloop was 
evenmin bevorderlijk voor een duurzame dialoog tussen de DSV, de vertegenwoordigers van de verenigingen en de wijkbewoners.

Die obstakels voor de geïntegreerde en projectmatige benadering die werd voorgesteld in de wijkcontracten, zouden wellicht niet zo belangrijk zijn geweest als het College van burgemeester en schepenen (PS-PRL-FDF) zelf niet zo verdeeld was. De meerderheid, die ook vandaag nog aan de macht is, liet elke schepen volledig vrij in de uitoefening van zijn bevoegdheden. Het gebrek aan politieke wil en de versnippering van het beleid versterkten elkaar. De administratieve weerstand had immers grotendeels overwonnen kunnen worden, als de verschillende betrokken schepenen de diensten die onder hun gezag stonden, opdracht hadden gegeven om samen te werken. De lokale politieke en administratieve cultuur paste zich dus vrij slecht aan de nieuwe aanpak van de gewestelijke instanties aan.

\section{Een nieuwe politieke en administratieve cultuur in Anderlecht}

Mettertijd werden bepaalde disfuncties weggewerkt dankzij veranderingen op politiek én administratief vlak. Die wijzigingen hangen niet noodzakelijk samen met de wijkcontracten, maar hebben een impact op het beheer ervan. Het samenspel van die wijzigingen verklaart dat de ingrepen in Kuregem geleidelijk gelegitimeerd werden en dat er nieuwe vormen van overheidsoptreden tot stand werden gebracht. Dankzij de nieuwe politieke en administratieve cultuur in de gemeente, die evenwel de oude cultuur niet heeft verdrongen, kon het beheer van de wijkcontracten worden verbeterd.

\subsection{Wijziging van het lokale politieke landschap}

Op politiek vlak heeft de gemeentelijke meerderheid haar houding gewijzigd zowel ten opzichte van de wijk als ten opzichte van de nieuwe praktijken die ingevoerd werden door de wijkcontracten. De politieke cultuur die in de jaren 1990 overheerste, verzwakte onder invloed van een langzame wijziging van het politieke landschap. In de dominerende partijen onderschreven de gemeentelijke politici gedeeltelijk en geleidelijk de doelstellingen van de wijkcontracten dankzij veranderingen op het lokale en het gewestelijke niveau. Eerst temperde J. Simonet, burgemeester van Anderlecht tussen 2001 en 2007, wegens zijn ambities in de gewestelijke en nationale politiek mettertijd zijn discours over de migranten (Goldman, 2000). Hij moedigde de ingrepen in de wijk niet echt aan, maar blokkeerde ze evenmin. Ten tweede werd Eric Tomas, tussen 2001 et 2006 de leider van de socialistische oppositie in de gemeenteraad van Anderlecht, in 1999 gewestelijk minister bevoegd voor stadsvernieuwing. Hij zorgde er mede voor dat de Anderlechtse socialisten de filosofie van de herwaardering van de wijken onderschreven en hij bevestigde de belangstelling van zijn partij voor Kuregem door verschillende wijkcontracten toe te kennen.

De vernieuwing van het politieke personeel droeg ook bij tot een andere houding van de lokale politieke klasse tegenover Kuregem. Eerst dient het pionierswerk van $P$. Reniers (PSC) te worden vermeld: hij is begonnen met de herwaardering van de wijk in het kader van de SBO. Vervolgens heeft de doorbraak van Ecolo op de lokale politieke scène bijgedragen tot een almaar grotere openheid van de lokale politieke elite voor een gericht ingrijpen in Kuregem en voor vormen van overheidsoptreden 
op basis van inspraak. Ten slotte forceerden de pensionering van C. D'Hoogh en de oppositiekuur van de PS in Anderlecht een zekere vernieuwing, wat meer armslag gaf aan de gekozenen die de nieuwe generatie van de PS belichamen, onder wie de gekozenen met Maghrebijnse roots die een minder stigmatiserend discours over de wijk en haar bewoners hebben.

Ten derde hebben de politieke partijen, met uitzondering van de extreemrechtse partijen, gelet op de wijzigingen van de criteria voor het verkrijgen van de Belgische nationaliteit voor onderdanen van EU-lidstaten en van landen buiten de EU en op de toekenning van stemrecht bij de gemeenteraadsverkiezingen aan buitenlandse verblijfhouders, hun strategie veranderd om de stemmen van die nieuwe kiezersgroep voor zich te winnen (Jacobs, Martiniello en Rea, 2002; Boussetta, 2006). Daardoor zijn gebieden waar zich grote bevolkingsgroepen uit de immigratie hebben gevestigd zoals Kuregem, electorale uitdagingen geworden en krijgen ze opnieuw aandacht van de politici. De politieke partijen beseffen het belang van die uitdaging, maar dat besef was in eerste instantie ingegeven door de behoeften om zich te onderscheiden in de lokale kiesstrijd.

De wijziging van het lokale politieke landschap ging ook gepaard met een vernieuwing en mentaliteitswijziging van het lokale administratieve personeel. De aanwerving van een nieuwe generatie administratieve personeelsleden die vanuit hun ervaring met verenigingswerk of door hun opleiding openstonden voor een geïntegreerde aanpak en voor de uitdagingen in de gevoelige wijken, heeft de coördinatie en samenwerking tusen de verschillende gemeentediensten vergemakkelijkt.

De vernieuwing heeft evenwel bepaalde overtuigingen niet volledig uitgeroeid. Overlast en kleine criminele feiten in het dagelijkse leven van de wijk blijven het argument van bepaalde politieke en institutionele actoren om bepaalde inrichtingsprojecten, zoals de aanleg van een voetgangerszone, die gefinancierd worden in het kader van dat overheidsbeleid, te weigeren of te wijzigen en om te pleiten voor een repressieve aanpak. Het wantrouwen tegenover bepaalde bevolkingsgroepen van Kuregem blijft bestaan en draagt bij tot de stigmatisering van de wijk.

In het nieuwe lokale politieke en administratieve landschap is er weliswaar nog geen leider opgestaan die de herwaardering van de wijk kan dragen, maar het overheidsoptreden in Kuregem heeft wel aan legitimiteit gewonnen en nieuwe vormen van overheidsingrepen werden aanvaard. De vernieuwing, die de vorm van een echte generatiekloof aanneemt, heeft bepaalde praktijken van de projectmatige aanpak ingang doen vinden. Afgezien van de ideologische voorkeuren, de politieke kleuren en de institutionele structuren, illustreren de gevolgen van de vernieuwing voor de uitvoering van de wijkcontracten het feit dat actoren die betrokken zijn bij het uitstippelen van het overheidsbeleid, niet onpartijdig zijn. Ze doordrengen het overheidsbeleid met hun ideeën, overtuigingen en handelwijzen. 


\subsection{Leerprocessen}

Dankzij de vernieuwing van het politieke en administratieve personeel in de gemeente Anderlecht hebben de wijkcontracten ook een leerproces op gang gebracht, want er werden voornamelijk uit de ervaringen van het verleden een aantal lessen getrokken. (Rose, 2005). Dat leerproces heeft er zowel toe geleid dat de gewestelijke actoren zich aan de lokale realiteit hebben aangepast en dat het lokale niveau zich aan de wijkcontracten heeft aangepast.

De gewestregering heeft de werking van de wijkcontracten meermaals herzien door de procedures 15 te preciseren: de inspraak werd meer in detail geregeld; de inhoud en de fasering van het basisprogramma dat ter goedkeuring werd voorgelegd aan de gewestregering, werden vastgesteld; er werden instrumenten ingevoerd om de gemeenten te ondersteunen. Het Gewestelijke Secretariaat voor Stedelijke Ontwikkeling (GSSO) was aldus gedurende enige tijd een instrument dat de gemeenten steunde bij het sturen van de deelnemende instanties en het vaststellen van het sociale deel. Het gewestelijke niveau heeft zich dus aangepast en rekening gehouden met de situatie in bepaalde gemeenten door het verticale en hiërarchische karakter van het programma te versterken.

Verschillende wijzigingen op gemeentelijk vlak hebben die leerprocessen mogelijk gemaakt.

De toename van het aantal programma's zoals de wijkcontracten heeft ertoe bijgedragen dat de geïntegreerde aanpak op lokaal niveau aangeleerd en verspreid werd. Enerzijds zijn er verschillende wijkcontracten na elkaar gesloten. Anderzijds hebben programma's van verschillende gezagsniveaus, zoals Urban II, Doelstelling 2, het FGSB of nog de Initiatiefwijken, het gewicht en de legitimiteit van de geïntegreerde aanpak, maar ook van de territoriale benadering van de meest achtergestelde wijken vergroot. Daardoor hebben ze die principes en nieuwe praktijken mede verspreid binnen de gemeenten.

De consolidatie van de DSV door de aanwerving van het ontbrekende personeel, de herziening van zijn werking en de vermindering van het personeelsverloop hebben ervoor gezorgd dat men lessen heeft getrokken uit de vorige ervaringen. Dat leidde tot een betere follow-up van de wijkcontracten, tot samenwerking, tot innoverende projecten en tot een langetermijnvisie op het gebruik en de financiering van de collectieve voorzieningen. Ondanks de administratieve versnippering die nog steeds bestaat, blijkt uit initiatieven zoals de organisatie van stedelijke workshops gewijd aan de Dauwwijk of nog uit het online plaatsen van documenten over het wijkcontract « Lemmens » door het Participatiehuis van Anderlecht dat er samenwerkingsvormen tot stand gebracht worden binnen het gemeentebestuur over de verschillende diensten heen en dat men zich autonomer opstelt tegenover de politiek door de knowhow, de kennis en de ervaring die men opdoet bij het uitvoeren van het programma.

Het feit dat de verenigingen, de bewoners of nog bepaalde gekozenen het falende gemeentelijke beheer van de wijkcontracten aankloegen, droeg eveneens bij tot de herziening van de beheersregels van de wijkcontracten. Enerzijds had dat te maken met de wijzigingen binnen de DSV. Anderzijds leidde dat protest tot een versnippe-

15 De ordonnantie van 7 oktober 1993 houdende herwaardering van de wijken werd tweemaal herzien bij de ordonnantie van 20 juli 2000 en die van 27 juli 2002. 
ring van de bevoegdheden in verband met de wijkcontracten tussen de verschillende betrokken schepenen. De nieuwe verdeling van de bevoegdheden binnen de gemeentelijke meerderheid (PS, CDH en FDF) strekt ertoe de onderbenutting van de financiële middelen tegen te gaan, de coördinatie tussen de gevoerde acties en de samenwerking tussen de schepenen te verbeteren, een gemeentelijke visie op het gebruik van de wijkcontracten te ontwikkelen, maar ook de financiële middelen te verdelen tussen de verschillende partners van de meerderheid.

Dit laatste punt toont aan dat er, afgezien van de breuklijnen en veranderingen, inertie blijft bestaan. In oktober 2006 hebben de politieke onderhandelingen tussen de partijen van de meerderheid (MR-PS-SPA-CDH), wegens de verkiezingsuitslag, het mandaat van de schepen die sinds 1997 bevoegd is voor de wijkcontracten, voor de derde keer hernieuwd, terwijl haar beheer van de wijkcontracten allang in verband gebracht wordt met een groot aantal vertragingen ${ }^{16}$. Ze heeft die bevoegdheid evenwel behouden, maar haar opdracht is voortaan beperkt tot het beheer van de delen betreffende de huisvesting en de coördinatie van het programma. Uiteindelijk zijn haar managementcapaciteiten van vrij weinig belang. Het feit dat die mening gedeeld wordt en tot geen tastbare wijzigingen leidt, heeft twee grote gevolgen. Eerst zijn er de teweeggebrachte effecten. Symbolisch gezien hebben talrijke bewoners en veldwerkers nog steeds het gevoel dat ze aan hun lot worden overgelaten en dat er niets gebeurt. Het tweede gevolg is dat men een en ander te weten komt over de verhoudingen tussen partijpolitiek en de noodzakelijke efficiëntie van het overheidsoptreden. Ondanks vele toespraken over goed lokaal bestuur en de verdiensten van de gemeentelijke autonomie, toont deze situatie aan dat twee politieke culturen naast elkaar bestaan en dat de oude politieke cultuur niet volledig verdwenen is.

\section{Conclusie}

De evolutie van het beheer van de wijkcontracten in Kuregem toont aan dat verschillende elementen interessant zijn voor de analyse van het overheidsbeleid. Eerst leidt een nieuw overheidsbeleid niet tot een volledige wijziging van het gedrag van de actoren en de instellingen die erbij betrokken zijn. De dwingende kracht van een overheidsbeleid is beperkt, maar bestaat. In Kuregem heeft het overheidsbeleid de aanzet gegeven tot de overgang van een afbraak- naar een herwaarderingsbeleid. Wil de overheid haar doelstellingen halen, dan moet ze kunnen vertrouwen op actoren die het eens zijn met haar principes en die over middelen beschikken om het overheidsbeleid concreet uit te voeren, want die actoren zijn niet onpartijdig. In Kuregem werden bepaalde disfuncties uit de wereld geholpen dankzij nieuw politiek en administratief personeel en een collectief leerproces. De wijkcontracten hebben geleidelijk steeds meer wijzigingen teweeggebracht. Ten slotte blijven de lokale politieke actoren, ondanks de diversifiëring van de actoren, een cruciale rol spelen in het overheidsbeleid: ze zijn in staat om bepaalde prioriteiten en aspecten van de werking van het gemeentebestuur te beïnvloeden.

16 VERSTRAETEN, Guy, « Vanpévenage doit s'expliquer. Jacques Simonet menace de lui retirer ses compétences », in Le Soir, 9 mei 2007. 


\section{Bibliografie}

BOUSETTA, Hassan, 2006, « Représentation politique et diversité culturelle: fragile exception bruxelloise ", in KHADER, Bichara ; MARTINIELLO, Marco ; REA, Andrea ; TIMmERMAN, Christiane, Ed., 2006, Penser l'immigration et l'intégration autrement, Bruxelles, Bruylant, pp. 115-123.

Delwit, Pascal; Deschouwer, Kris, 2009, " De Brusselse instellingen », in Brussels Studies, Staten-Generaal van Brussel : Synthesenota nr. 14, 10 p.

DE MAILLARD, Jacques, 2002, « Les nouvelles politiques socio-urbaines contractuelles entre conflits et apprentissages », in Politix, Vol. 15, n 60, pp. 169-191.

Goldman, Henri, 2000, « Anderlecht, le gâchis », Politique, Juillet-Août, n 17, pp. 20-23.

IMMERGUT, Ellen M., 1992, «The Rules of the Game: the Logic of Health Policy-Making in France, Switzerland, and Sweden ", in StEINMO, Sven; THELEN, Kathleen; LONGSTRENGTH, Franck (dir.), Structuring Politics: Historical Institutionalism in Comparative Analysis, Cambridge, Cambridge University Press, pp. 57-89.

JACOBS, Dirk; MARTINIELLO, Marco; REA, Andrea, 2002, « Changing patterns of political participation of citizens of immigrant origin in the Brussels Capital Region: the October 2000 elections ", in Journal of international migration and integration, Vol. 3, n² , pp. 201-221.

JACQUIER, Claude, 1991, Voyage dans dix quartiers européens en crise, Paris, L'Harmattan, $127 \mathrm{p}$.

MISTIAEN, Pascale, 1994, "Cureghem en crise ? Les processus de marginalisation d'un quartier bruxellois ", in GoOsSENS, Modest; VAN HECKE, Etienne, sous la dir., Van Brussel tot Siederburgen. Liber amicorum Herman Van Der Haegen, in Acta Geographica Loveniensia, n 34 , pp. 361-374.

Mistiaen, Pascale; MeERT, Hendrick; Kesteloot, Christian, 1995, « Polarisation socio-spatiale et stratégies de survie dans deux quartiers bruxellois ", in EspacePopulations-Sociétés, $\mathrm{n}^{\circ}$ 3, pp. 277-290.

NAGELS, Carla; REA, Andrea, 2007, Jeunes à perpète. Génération à problèmes ou problème de générations, Bruxelles, Academia Bruylant, 165 p.

NoËL, Françoise, 1998, La ville rapiécée: les stratégies de la réhabilitation à Bruxelles, Bruxelles, Editions de l'Université de Bruxelles, $189 \mathrm{p}$.

PINSON, Gilles, 2004, "Le projet urbain comme instrument d'action publique », in LASCOUMES, Pierre; LE GALĖS, Patrick, Gouverner par les instruments, Paris, Presses de Sciences Po, pp. 199-233.

REA, Andrea, 1999, Immigration, Etat et citoyenneté. La formation de la politique d'intégration des immigrés de la Belgique, Bruxelles, Thèse de doctorat de la Faculté SOCO de l'Université libre de Bruxelles, 1424 p.

REA, Andrea, 2006, "Les politiques d'immigration: des migrations ordonnées aux migrations débridées ", in KHADER, Bichara; MARTINIELLO, Marc ; REA, Andrea ; 
Timmerman, Christiane, Ed., 2006, Penser l'immigration et l'intégration autrement, Bruxelles, Bruylant, pp. 177-207.

Rose, Richard, 2005, Learning from Comparative Public Policy. A Practical Guide, Routledge, New York, 150 p.

SCHAUT, Christine, 2007, "Des politiques à l'épreuve de la ville ", in Revue Bis, $n^{\circ}$ 158, pp. 5-11.

SCHOONBRODT, René, 2007, Pouvoir et dire la ville, Bruxelles, Archives d'architectures modernes, $519 \mathrm{p}$.

THIBAULT, Catherine, 2001, "Les Contrats de quartier », in Revue Bis, n 148, pp. 17-27.

TouzRI, Abdelfattah, 2007, Développement local, acteurs et action collective. Les minorités issues de l'immigration et les dispositifs de revitalisation urbaine dans la commune de Molenbeek-Saint-Jean, Louvain-La-Neuve, Presses universitaires de Louvain, $344 \mathrm{p}$.

VAn CRIEKINGEN, Mathieu; Charles, Julies, 2007, «Politiques urbaines, migrations et profils socio-économiques en Région de Bruxelles-Capitale ", in Revue Bis, $\mathrm{n}^{\circ}$ 158, pp. 34-38. 